\title{
The Social Wasp Fauna and Biology of Khorezm Region (Hymenoptera, Vespidae: Vespinae, Polistinae)
}

\author{
Ulmasbek R. Abdullaev ${ }^{1}$, Ikram I. Abdullaev ${ }^{1} \&$ Oygul O. Masharipova ${ }^{2}$ \\ ${ }^{1}$ Khorezm Academy of Mamun, Khiva, Uzbekistan \\ ${ }^{2}$ School № 19 of Khazarasp district \\ Correspondence: Ulmasbek R. Abdullaev, PhD student academy of Mamun, 220900, Khiva, Uzbekistan. Tel: \\ 998-362-224-6644. E-mail: abdullayev.ulmasbek@mail.ru
}

Received: October 4, 2019

Accepted: October 17, 2019

Online Published: October 24, 2019

doi:10.5539/ijb.v12n1p14

URL: https://doi.org/10.5539/ijb.v12n1p14

\begin{abstract}
For the first time in Uzbekistan, there was a research on four species of Poleses dominula (Christ, 1791) and Polistes wattiim (Cameron, 1900), Vespula germanica (Fabricius, 1793), Vespa orientalis (Linnaeus, 1771) in Vespinae, Polistinae 2 subspecies of Vespidae family in Khorezm region species composition, distribution and their biology.
\end{abstract}

Keywords: Biological Control, Diversity, Polistiae, Urban Forestry, Vespidae

\section{Introduction}

Social wasps (Hymenoptera: Vespidae) belong to the subfamilies Polistinae, Stenogastrinae and Vespinae. Social wasps are an important part of food webs, preying on insects of the orders Coleoptera, Diptera, Hemiptera, Hymenoptera and Lepidoptera in terrestrial ecosystems (Souza et al., 2013). Social wasps are important natural enemies of insect pests and their diversity is similar or even higher in urban areas than in natural environments (Landolt, 1999; Jacques et al., 2012). Representatives of the Vespidae family are the largest of the species by the number of species of insects. In the world fauna, there are 5274 species of bees whose six small families are 256 generations (Antropov \& Fatery, 2017). There are 1046 species in the Polearctic and 817 in 31 generations in Russia (Kurzenko, 1995). Previously, the three youngest families were divided. Team or Pumpkin Bees (Vespidae), Flower Bees (Masaridae) (Eumenidae). Today, all social wasps are united into the Vespidae family Euparagiinae, Masarinae, Eumeninae, Stenogastrinae, Vespinae, and Polistinae keja (Kurzenko, 2012).

Social wasps as one of the massive groups of insects play a prominent role in many natural complexes. This interesting group of arthropods in the domestic literature has received little attention. The ecology of public folded-winged wasps in Uzbekistan and, in particular, in the Khorezm region has not been studied at all. This circumstance determined the purpose and objectives of our research. The purpose of the work is to identify the environmental features of public folded-winged wasps in the Khorezm region. Tasks: - to clarify the species composition and conduct a zoogeographic analysis of the fauna of the public folded-winged wasps of the region; study the structure and dynamics of wasp communities and determine the basic laws of their formation; - to identify the features of the distribution, ecology of reproduction and nutrition of the genus Polistes and Vespula. Our present research is the first scientific basis for the study of species composition, biology and ecology of the Vespidae family in Uzbekistan, particularly in the Khorezm region, and will help to improve the Vespidae systematization in the future.

\section{Materials and Methods}

\subsection{Study Area}

The area is a lowland plant located in the NW part of Uzbekistan, along the lower reaches of the amu darya river, between $60^{\circ} \mathrm{C}-61^{\circ} \mathrm{C}$ longitude and $41^{\circ} \mathrm{C}-42^{\circ} \mathrm{C}$ latitude, at $113-138 \mathrm{~m}$ above sea level. The climate is extremely continental, with an average annual precipitation of $80-90 \mathrm{~mm}$. Average temperature in January is $-5^{\circ} \mathrm{C}$, in July $+30^{\circ} \mathrm{C}$. Meadow, meadow marshly, marsh-sandy a typical alkali soils prevail. The climate of the oasis is greatly influenced by the deserts of Kyzylkum and Karakum (Rudenko et al., 2009). 
Studies were conducted in the Khorezm regions in 2017-2019. For three seasons, covering the entire period of the image of summer from March to September was spent to identify species diversity; studies were conducted in weighted areas in Khorezm regions (Figure 1).
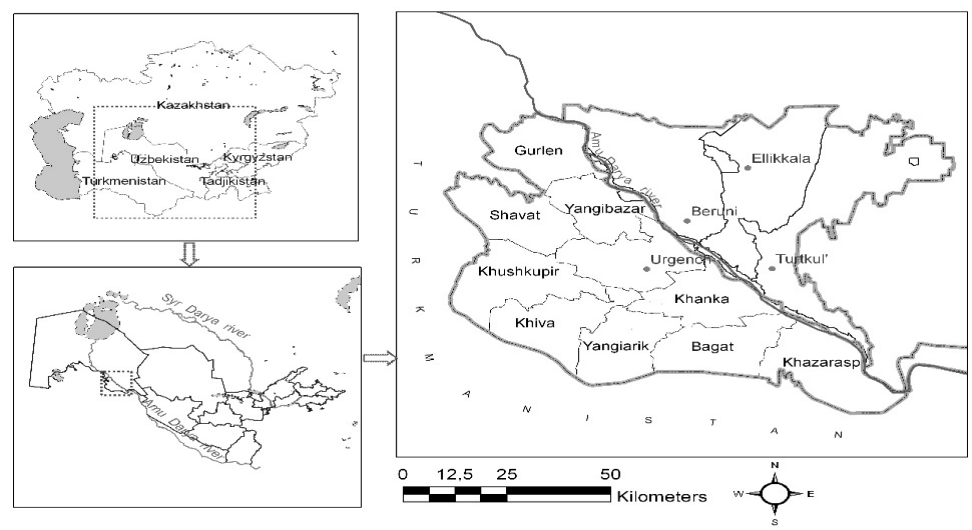

Figure 1. Map Khorezm region

The traditional method of collecting materials was entomological net, Mericle molding vessels (Golub, 2012; Moericke, 1951) (Figure 2). During the study, more than 1,000 bees of 5 species were caught. Specification of the species composition of the Vespidae bees was used by comparative charts of foreign scientists and the insect catalog (Stephen \& Marshall, 2006).
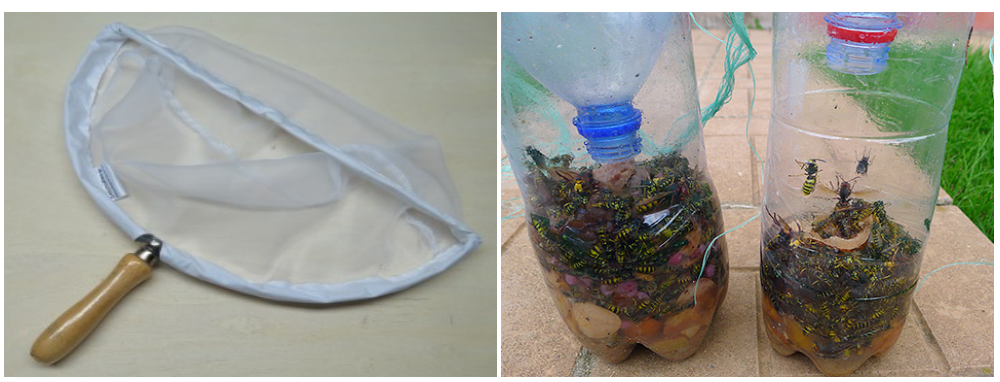

Figure 2. Entomological net and insect trap

In total, over 3,000 trap-days were worked out in 3 seasons. Over 1200 copies of collection material were collected, not including material without exception, relating to 5 species from 4 generations and 2 subfamilies. The determination of adults and measurement of the parameters of the nest cells was carried out using the stereoscopic binocular MBS-2. The collected material was identified by determinants (Yamane, 1980; Archer, 1989; Kurzenko, 1995; Pekkarinen, 1995). To confirm the correct definition of species, collection materials of the Siberian Zoological Museum were reviewed.

\section{Results and Discussion}

To date, in the Khorezm region (Uzbekistan), the habitat of 6 species of public wasps from 4 genera belonging to 4 subfamilies has been registered and confirmed with original collections (Table 1).

Table 1. The taxonomic structure of the public fold-winged wasps in the Khorezm region

\begin{tabular}{llll}
\hline Family & subfamily & Genus & species \\
\hline & Vespinae & Vespula & V. germanica $F$. \\
Vespidae & Eumeninae & Vespa & V.orientalis $L$. \\
& Stenogastrinae & Eumenes & E. mediterraneus $K$. \\
& Polistinae & & Avispa alfarera \\
Total & 4 & Polistes & P. dominula Ch., \\
& & 4 & . wattiim $C$. \\
\hline
\end{tabular}


In our study conducted in all districts of the Khorezm region in 2019, four species of Vespidae family bees Polistes dominula (Christ, 1791), Polista Vatti Polistes wattiim (Cameron, 1900), Vespula germanica (Fabricius, 1793) and Vespa. It is noted that the species Vespa orientalis (Linnaeus, 1771).

Class: Insecta

Order: Hymenoptera

Family: Vespidae

Subfamily: Polistinae

Genus: Polistes

Species: Polistes dominula (Christ, 1791)

Distribution: Khorezm region all district (Uzbekistan)

Description. The color is dominated by yellow. Antennae yellow, except for the first three segments. The pattern on the clypeus is variable: in the form of a transverse strip or a speck. Mandibles are black. Abdomen without long spaced hairs, fusiform. 1st tergite to base gradually narrowed, not abrupt. The 6th sternite of the abdomen of females is yellow or black only at the base. The color of the abdomen is dominated by yellow. The hind wings in the main part are not narrow. The introduction and rapid spread of $P$. dominula in Khorezm region has spawned a series of investigations on its biology. P.dominula has become much more abundant in urban and suburban areas. Fore wing length 9.0-12.5mm (웅), 8.0-11.5 (ðત). (Figure 3).
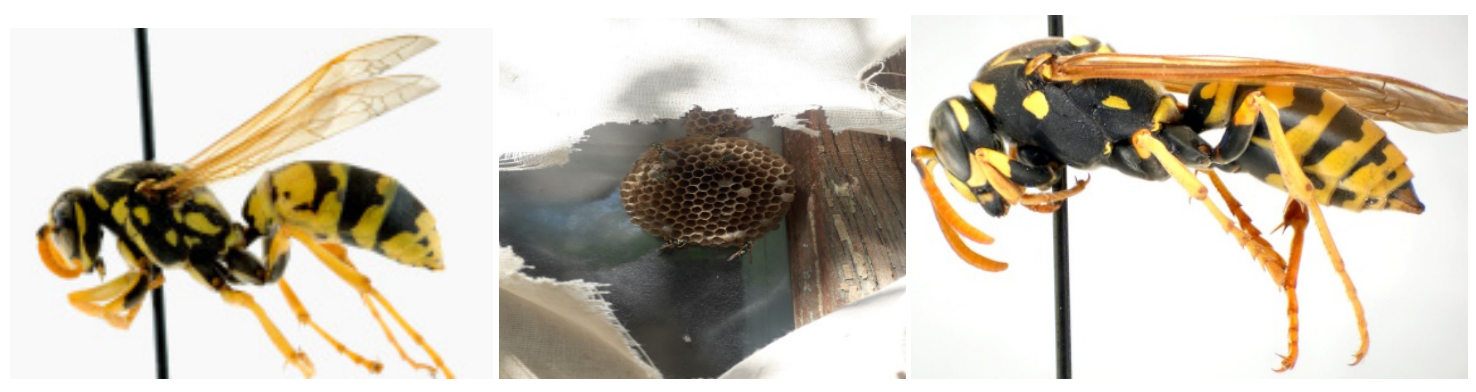

Figure 3. Polistes dominula (Christ, 1791)

Class: Insecta

Order: Hymenoptera

Family: Vespidae

Genus: Vespula

Subfamily: Vespinae

Species: Vespula germanica (Fabricius, 1793)

Distribution: Khorezm region all district (Uzbekistan)

Description. $V$. germanica in the Khorezm region are one of the most widespread types of public wasps, and in cities, in fact, the only dominant species of wasps, they compete in number with polistes. Nest are usually subterranean but are also built in hollow walls, in roofs, attics, etc. Prey consists of a wide variety of arthropods; in addition females scavenge on carrion and meat. Vespula germanica are the most common pest yellowjackets in the

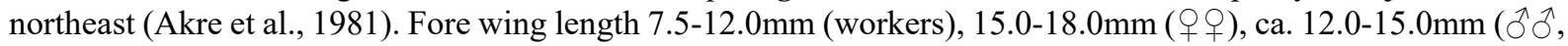
$\mathrm{n}=7) . V$. germanica are social insects, in our climate their nest consists of one uterus - a fertilized female, unfertilized working individuals, and also lost the ability to mate individuals, nevertheless capable of laying eggs, males, and unfertilized females of future queens. These have a clearly expressed sociality, which is expressed in a combination of several characteristics: in the division of functions between individuals - the uterus and working wasps, in the fact that in the same nest the female founder meets and interacts with her offspring until the offspring of females and males, workers take care of offspring that do not belong to them (Figure 4). 


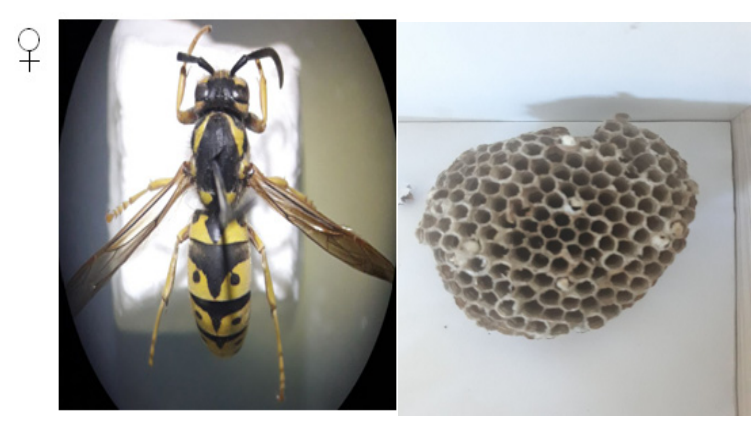

Figure 4. Vespula germanica (Fabricius, 1793)

\section{Class: Insecta}

\section{Order: Hymenoptera}

Family: Vespidae

\section{Genus: Polistes}

Subfamily: Polistinae

Species: Polistes wattiim (Cameron,1900)

\section{Distribution: Khorezm region all district (Uzbekistan)}

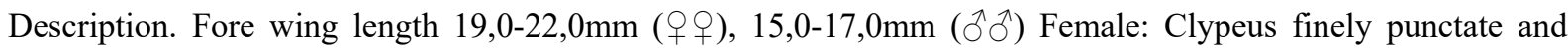
interposed with scattered larger deep punctures; supraclypeal area, interantennal space, inner orbit including ocular sinus, frons, vertex, temple, pronotum, meso scutum, scutellum, postscutellum mat; malar space with scattered punctures; occipital carina complete; mesepisternum behind epicnemial carina mat with scattered fine punctures; dorsal and ventral metapleuron impunctate; striations on propodeum weak, not distinct near the lower margin of side; gaster smooth covered with short pubescence; first gastral sternite smooth.

Male: Similar to female except clypeus not touching the eye; proximal tooth shorter and broader than other teeth; temple wider; apophyses of subgenital plate long and narrow, not flattened at apex, densely pubescent. Polistes wattiim in appearance, they are different from other types of Polistes in Uzbekistan. The body is almost flat yellow; In some species, the middle breast has a yellowish brown, and sometimes has a black spot on the top of the mustache, with a small black line around each eye (Figure 5). The upper part of the hind leg is black. First abdomen with narrow transverse reddish brown, curved reddish line in section 2-5; Some species have 2 curved lines on the anterior breast. The number is more than 100, with the appearance of a single bee, as well as other polistes, in light gray, in a few dozen cells. Trees build nests in horns, poles, house walls and ceilings, balconies, and attics. It feeds its larvae with a variety of insects, including carnivores, mammals and worms. At the final stage of individual formation, the polysomes are fed with flowers like other species.

Harmful Tariffs: It ripens; damages fruit ripened in trees, and sometimes causes damage to fruits and stocks as well as food during drying and processing. Occasionally, the original carrier will attack the weak nests of bees, kill the bees and steal honey to feed their larvae. As well as other common bees, it can collect food from the waste for its larvae. The poison is strong.

New data have been obtained on the distribution of two species of common folded-winged wasps in the Republic of Uzbekistan, Vespa orientalis (Linnaeus, 1771) (eastern or Turkestan hornet), and Polistes wattii Cameron, 1900 (polista Watti). Currently, in the Khorezm region there is a stable self-reproducing population of V.orientalis, and its range is constantly expanding. $P$. wattii in the Khorezm region was noted relatively recently (2014, areas of the Khazarasp, Shavat and Khiva region in the Khorezm region). 


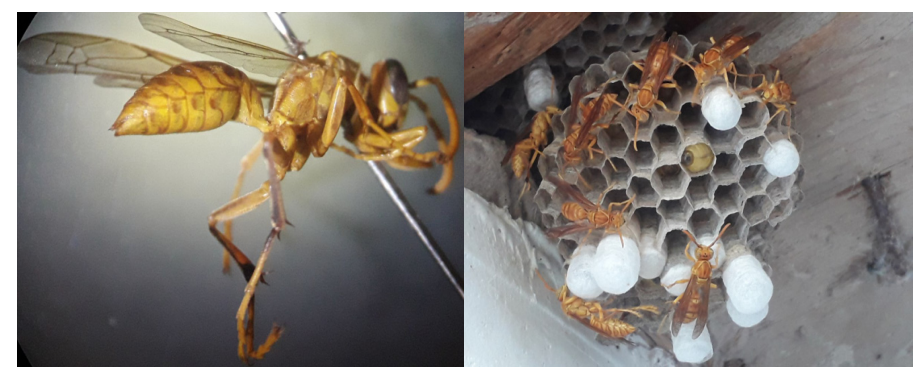

Figure 5. Polistes wattiim (Cameron,1900)

Class: Insecta

Order: Hymenoptera

Family: Vespidae

Genus: Vespa

Subfamily: Vespinae

Species: Vespa orientalis Linnaeus, 1771

Distribution: Khorezm region all district (Uzbekistan)

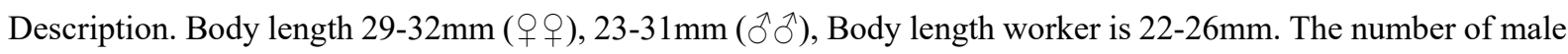
mustache segments is 13, and the females always 12 (Figure 6). The head is reddish-brown, the face is yellow. Her chest is brown. Most of the abdomen is brown, and the third and third segments are yellow. Each segment has 2 brown spots on the yellow background. Whiskers and feet are reddish-brown, and the hind legs and feet are more or less yellow. According to Israeli and British scientists, xantopretin spots on the yellowish part of the Vespa orientalis in the abdomen have absorbed the sun's rays and converted them into electricity. So these pumpkin bees are very active on sunny days.

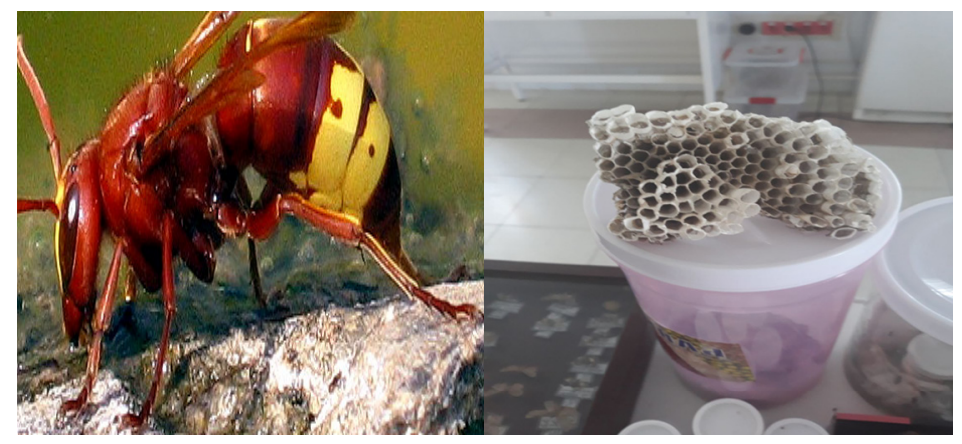

Figure 5. Vespa orientalis (Linnaeus, 1771)

They build their nests in tree holes, holes in rocky cliffs, on walls and under roofs. A rectangular and double-horned beetle for larvae, such as a dragonfly, hunt for beetles. Vespula and Polistes bees, and spiders are also hunted. Citrus damages ripe fruits such as apricots, grapes, peaches, plums and Gnawing bark of seedlings and young fruit trees. They also damage the forestry and beekeeping, which means they kill about 33 bees in one hour to feed offspring and damage food. It can cause severe complications as a result of bites to humans and livestock. In the first study, six species of Vespidae family were found in all districts of Khorezm region: Polistes dominula (Christ, 1791), Polistes wattiim (Cameron, 1900), Vespula germanica (Fabricius, 1793), Vespa orientalis (Linnaeus, 1771) and Eumenes mediterraneus (Kriechbaumer, 1879), Avispa alfarera recorded.

Thus, these studies are the first studies in the Khorezm region, and in the future the Vespidae family of the Khorezm oasis will play an important role in the complete study of the species composition and the formation of the existing systematics of wasps. Research works are also underway to study their bioecological features and distribution, zoogeographical analysis, to study the structure and dynamics of true bees and to reveal the basic patterns of their formation. 


\section{Acknowledgments}

The author is grateful to the director of the Zoological Institute of the Academy of Sciences of the Republic of Uzbekistan for providing research facilities and encouragements.

\section{Conflict of interests}

The authors declare that there is no conflict of interests regarding the publication of this paper.

\section{References}

Antropov, A. V., \& Fateryga, A. V. (2017). Superfamily Vespoidea, 68. Family Vespidae. In Book:

De Souza, A. R., Venâncio, D. F. A., \& Prezoto, F. (2010). Social wasps (Hymenoptera: Vespidae: Polistinae) damaging fruits of Myrciaria sp. (Myrtaceae). Sociobiology, 55, $297-299$.

Golub, V. B. (2012). Insect collections: Collection, processing and storage of material. In V. B. Golub, M. N. Tsurikov, \& A. A. Prokin (Eds.), Partnership of scientific publications of KMK (p. 339).

Jacques, G. C., Castro, A. A., Souza, G. K., Silva-Filho, R., De Souza, M. M., \& Zanuncio, J. C. (2012). Diversity of social wasps on the campus of the "Universidade Federal de Viçosa" in Viçosa, Minas Gerais State, Brazil. Sociobiology, 59, 1053-1062.

Kurzenko, N. V. (1995). Fam. Vepsidae In: A key to insects from the Far East of Russia (Vol. 4, pp. 264-324). Neuropteroidea, Mecoptera, Hymenoptera. Pat 1. - St-Peterburg.

Kurzenko, N. V. (2012). Fam. Vespidae-folded wasps: Annotated catalog of insects in the Russian Far East (pp. 415-423). T. 1: Hymenoptera. Vladivostok: Dalnauka.

Landolt, P. J. (1999). Social wasps (Hymenoptera: Vespidae) trapped with acetic acid and isobutanol. In P. J. Landolt, H. C. Reed, \& J. R. Aldrich (Eds.), Florida Entomologist (Vol. 82, No. 4, pp. 609-614).

Marshall, S. A. (2006). Insects Their Natural History and Diversity (p. 732). With a photographic guide to insects of eastern North America. Published by Firefly Books Ltd.

Moericke, V. (1951). Eine farbfalle zur Kontrolle des Fluges von Blattläusen, insbesondere der Pfirsichblattlaus, Myzodes persicae (Sulz). Nachrichtenbl. Deutsch. Pflanzenschutzd, Braunschweig, 3, 23-24.

Picanço, M. C., Bacci, L., Queiroz, R. B., Silva, G. A., Miranda, M. M. M., Leite, G. L. D., \& Suinaga, F. A. (2011). Social wasp predators of Tuta absoluta. Sociobiology, 58, 621-633.

Picanço, M. C., De Oliveira, I. R., Rosado, J. F., Da Silva, F. M., Gontijo, P. D., \& Da Silva, R. S. (2010). Natural biological control of Ascia monuste by the social wasp Polybia ignobilis (Hymenoptera: Vespidae). Sociobiology, 56, 67-76.

Prezoto, F., Lima, M. A. P., \& Machado, V. L. L. (2005). Survey of preys captured and used by Polybia platycephala (Richards) (Hymenoptera: Vespidae: Epiponini). Neotrop. Entomol., 34, 849-851.

Richter, M. R. (2000). Social wasp (Hymenoptera: Vespidae) foraging behavior. Annu. Rev. Entomol., 45, 121-150.

Rudenko, I., \& Lamers, J. P. A. (2009). Ulrike Grote Can Uzbek Farmers get More for their Cotton? The European Journal of Development Research, 21, 283-296

Schmitz, J., \& Moritz, R. F. A. (1998). Molecular phylogeny of Vespidae (Hymenoptera) and the evolution of sociality in wasps. Mol. Phylogenet. Evol., 9, 183-191.

Souza, G. K., Pikart, T. G., Jacques, G. C., Castro, A. A., De Souza, M. M., Serrão, J. E., \& Zanuncio, J. C. (2013). Social Wasps on Eugenia uniflora Linnaeus (Myrtaceae) Plants in an Urban Area Sociobiology, 60(2), 204-209.

Torezan-Silingardi, H. M. (2011). Predatory behavior of Pachodynerus brevithorax (Hymenoptera: Vespidae, Eumeninae) on endophytic herbivore beetles in the Brazilian Tropical Savanna. Sociobiology, 57, $181-189$.

Yamane, S. K., Wagner, R. E., \& Yamane, S. (1980). A tentative revision of the subgenus Paravespula of Eastern Asia (Hymenoptera, Vespidae). Insecta Matsumurana, 19, 1-46

\section{Copyrights}

Copyright for this article is retained by the author(s), with first publication rights granted to the journal.

This is an open-access article distributed under the terms and conditions of the Creative Commons Attribution license (http://creativecommons.org/licenses/by/4.0/). 